\title{
Hot-water immersion increases popliteal artery shear stress in Peripheral Arterial Disease
}

\author{
Kate N Thomas ${ }^{1,3^{*}}$, Andre M Van Rij ${ }^{1}$, Samuel JE Lucas ${ }^{2,4}$, James D Cotter ${ }^{3}$ \\ From 15th International Conference on Environmental Ergonomics (ICEE XV) \\ Portsmouth, UK. 28 June - 3 July 2015
}

\begin{abstract}
Introduction
Exercise improves peripheral vascular function in healthy and diseased populations; this is partly attributed to the exposure of the endothelium to transient, repetitive increases in blood flow and antegrade shear stress [1]. Traditional exercise poses significant barriers for patients with Peripheral Arterial Disease (PAD), as the condition manifests as debilitating walking-induced muscle pain (claudication) caused by obstruction to blood flow. PAD patients represent a large cohort who might therefore benefit from an alternative approach to exercise. Local limb heating in young, healthy adults has been shown to induce blood flow patterns indicative of promoting beneficial adaptations in peripheral arteries [2-4]. Additionally, preliminary evidence exists demonstrating sauna therapy improves symptoms and clinical indices in PAD [5]. The aim of this study was to investigate the acute vascular and cardiovascular responses to heat by lower limb hot-water immersion in patients with PAD and in healthy, elderly controls.
\end{abstract}

\section{Methods}

Eight patients with PAD (6 male, age $69 \pm 5$ y) and nine controls free from PAD (8 male, age $71 \pm 6 \mathrm{y}$ ) underwent hot-water immersion $(30 \mathrm{~min}$ immersed to the waist in water at $42-43^{\circ} \mathrm{C}$ ). Using high-resolution ultrasound, the popliteal artery diameter and blood flow was assessed before, during the last $3 \mathrm{~min}$ and 30 min after immersion in order to calculate the shear stress stimulus on the endothelium. Blood pressure and heart rate were continuously assessed using finger photoplethysmography.

\footnotetext{
* Correspondence: kate.thomas@otago.ac.nz

'Department of Surgical Sciences, University of Otago, Dunedin, New Zealand

Full list of author information is available at the end of the article
}

\section{Results}

Antegrade popliteal shear rate increased more than three-fold during water immersion in both PAD (mean \pm SD: $\left.+112 \pm 79 \mathrm{~s}^{-1}, p<0.01\right)$ and controls $\left(+74 \pm 51 \mathrm{~s}^{-1}\right.$, $p<0.01)$. At $30 \mathrm{~min}$ after immersion, shear rate remained elevated above baseline levels, although not significantly so for PAD (PAD: $+25 \pm 33 \mathrm{~s}^{-1}, p=0.09$ vs. baseline, controls: $\left.+15 \pm 14 \mathrm{~s}^{-1}, p=0.01\right)$. Retrograde shear was absent in PAD throughout but significantly decreased during immersion in controls $\left(-8 \pm 5 \mathrm{~s}^{-1}, p<\right.$ $0.01)$. Systolic (SBP) and diastolic blood pressure (DBP) were reduced $(p<0.001)$ during water immersion in PAD and controls to a similar extent: SBP in PAD, $-36 \pm$ $21 \mathrm{~mm} \mathrm{Hg}$, controls, $-32 \pm 13 \mathrm{~mm} \mathrm{Hg}$; DBP, $-14 \pm 7$ and $-12 \pm 8 \mathrm{~mm} \mathrm{Hg}$, respectively ( $p>0.05$ for interaction effects). SBP remained lower than baseline in both groups $30 \mathrm{~min}$ after immersion $(p<0.01)$. Heart rate increased similarly between groups, by $19 \pm 11$ beats. $\mathrm{min}^{-1}$ in PAD and $27 \pm 14$ beats. $\mathrm{min}^{-1}$ in controls (time: $p<0.001$; interaction: $p=0.16$ ).

\section{Discussion}

A single bout of hot-water immersion induced favourable shear stress patterns in the popliteal artery of PAD patients and healthy, elderly controls. This heat stress also induced a marked blood pressure-lowering effect, valuable particularly in a PAD population, who are commonly hypertensive yet unable to exploit the post-exercise hypotensive effect.

\section{Conclusion}

Considering the shear stress and blood pressure effects demonstrated in this study, heat stress, if repeated, has potential to result in beneficial vascular adaptations for a group with limited access to exercise; although this remains to be confirmed. 


\section{Authors' details}

'Department of Surgical Sciences, University of Otago, Dunedin, New Zealand. ${ }^{2}$ Department of Physiology, University of Otago, Dunedin, New Zealand. ${ }^{3}$ School of Physical Education, Sport and Exercise Sciences, University of Otago, Dunedin, New Zealand. ${ }^{4}$ School of Sport, Exercise and Rehabilitation Sciences, University of Birmingham, Birmingham, UK.

Published: 14 September 2015

\section{References}

1. Laughlin, et al: Importance of hemodynamic forces as signals for exercise-induced changes in endothelial cell phenotype. J Appl Physiol 2008, 104(3):588-600

2. Tinken $T M$, et al: Impact of shear rate modulation on vascular function in humans. Hypertension 2009, 54(2):278-85.

3. Carter $\mathrm{HH}$, et al: Repeated core temperature elevation induces conduit artery adaptation in humans. Eur J Appl Physiol 2014, 114(4):859-865.

4. Thomas KN, et al: in 15th International Conference on Environmental Ergonomics Queenstown, New Zealand; 2013.

5. Tei $C$, et al: Waon therapy improves peripheral arterial disease. J Am Coll Cardiol 2007, 50(22):2169-71.

doi:10.1186/2046-7648-4-S1-A111

Cite this article as: Thomas et al:: Hot-water immersion increases popliteal artery shear stress in Peripheral Arterial Disease. Extreme Physiology \& Medicine 2015 4(Suppl 1):A111.

\section{Submit your next manuscript to BioMed Central and take full advantage of:}

- Convenient online submission

- Thorough peer review

- No space constraints or color figure charges

- Immediate publication on acceptance

- Inclusion in PubMed, CAS, Scopus and Google Scholar

- Research which is freely available for redistribution

Submit your manuscript at www.biomedcentral.com/submit 